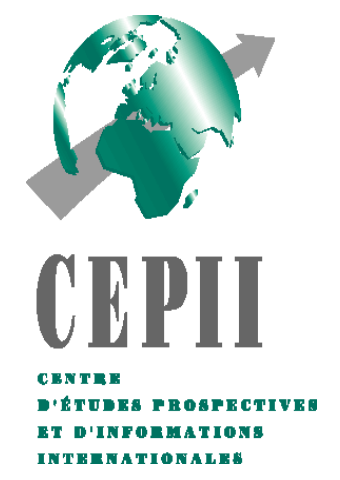

No 2005 - 05

April

\title{
Institutional Determinants of Foreign Direct Investment
}

Agnès Bénassy-Quéré Maylis Coupet Thierry Mayer 


\section{Contents}

$\begin{array}{llr}1 & \text { Introduction } & 8\end{array}$

2 The basic gravity model on bilateral FDI stocks 12

3 Data on institutions $\quad 14$

4 The impact of institutions in the host country 17

5 Institutional distance $\quad 22$

6 Alternative sources of institutional data 25

$\begin{array}{llr}7 & \text { Conclusion } & 28\end{array}$

8 References $\quad 28$ 


\section{InSTITUTIONAL Determinants OF FOREIGN DireCt INVESTMENT ${ }^{1}$}

\section{SUMMARY}

Since the late 1990s, the literature on economic development has been renewed by focusing on the quality of domestic institutions as a key explanation of cross-country differences in both growth rates and income per capita. Efficient protection of civil and property rights, extended economic and political freedom and low level of corruption have been in particular shown to be associated with higher prosperity. Simultaneously, there has been a growing interest in the determinants of foreign direct investment (FDI) in developing countries, as FDI is considered one of the most stable component of capital flows to developing countries and can also be a vehicle for technological progress through the use and dissemination of improved production techniques. Not surprisingly, thus, a number of authors have also studied the link between institutions and FDI. Because FDI is now a very large share of capital formation in poor countries, the FDI-promoting effect of good institutions might be an important channel of their overall effect on growth and development.

This paper contributes to the empirical literature dealing with the impact of the institutional environment on FDI in several ways. First, we re-examine the role of governance infrastructure in the host and in the source country by estimating a gravity equation for bilateral FDI stocks that includes governance indicators for the two countries. Second, we tackle multicollinearity and endogeneity bias by systematically comparing estimations with and without GDP per capita (which is likely to be correlated to various measures of institutional quality), by using two-stage estimations, and by instrumenting governance variables when necessary. Third, we look further into the detail of institutions by using the Institutional Profiles database constructed by the French Ministry of Finance network in 52 foreign countries for Year 2001. This database is used to point out in some detail the relevant institutional features. We also look for the most proximate variables in other existing databases and compare the results when those are used. When possible, panel data estimations are also carried out. Finally, we study the impact of institutional distance on bilateral FDI.

We find that institutions matter independently of GDP per capita. Our results point out public efficiency in a broad sense as a major determinant of inward FDI. This includes tax systems, easiness to create a company, lack of corruption, transparency, contract law, security of property rights, efficiency of justice and prudential standards. The extent of competition is also shown to matter, although capital concentration in both the source and the destination country has a positive impact on FDI.

While "good" institutions almost always increase the amount of FDI received, no general result applies to outward FDI. Finally, panel data regressions show that institutional distance

${ }^{1}$ We are grateful to Jacques Ould-Aoudia for helpful discussions 
tends to reduce bilateral FDI, although our results are much more mixed in the cross section dimension.

These results are encouraging in the sense that efforts towards raising the quality of institutions and making them converge towards those of source countries may help developing countries to receive more FDI, hence help them to catch up, independently of the indirect impact of higher GDP per capita. The orders of magnitude found in the paper are large. For instance, moving from a low level to a high level of institutional quality could have as much impact as suddenly becoming a neighbor of a large source country.

\section{Abstract}

In this paper, we contribute to the literature on the determinants of FDI in developing countries and re-evaluate the role of the quality of institutions on FDI. We use a newly available database, with unprecedented detail on institutions of a set of 52 countries, and compare the results with matched variables from more familiar datasets. The paper controls for the correlation between institutions and GDP per capita of the host country, and also accounts for potential endogeneity of institutions. Finally, we evaluate whether proximity of institutions between the host and the origin country raises bilateral FDI.

JEL classification: F23, R3

Keywords: Foreign Direct Investment, Gravity model, Institutions, Developing countries. 


\section{LES DÉTERMINANTS INSTITUTIONNELS DE L'INVESTISSEMENT DIRECT À} L'ÉTRANGER.

\section{RÉSUMÉ}

Depuis la fin des années quatre-vingt dix, la littérature sur le développement économique s'est profondément renouvelée en attirant l'attention sur la qualité des institutions comme facteur explicatif des différences entre pays de taux de croissance comme de niveaux de PIB par habitant. Une protection efficace des droits civils et des droits de propriété, une grande liberté économique et politique, un faible niveau de corruption ont en particulier été associés à une plus grande prospérité. Dans le même temps, l'intérêt pour les déterminants de l'investissement direct à l'étranger (IDE) s'est renforcé, l'IDE étant considéré comme l'un des composants les plus stables des flux de capitaux vers les économies en développement et comme un vecteur de progrès technique via l'utilisation et la diffusion des technologies importées. Logiquement, un certain nombre d'auteurs se sont alors intéressés aux déterminants institutionnels de l'IDE. Cette forme d'investissement occupant maintenant une grande place dans la formation du capital fixe dans les économies émergentes, encourager l'IDE par de meilleurs institutions pourrait s'avérer un moyen efficace pour accélérer la croissance et le développement.

Le présent article contribue de plusieurs manières à la littérature empirique cherchant à mesurer l'impact de l'environnement institutionnel sur l'IDE. Premièrement, nous réexaminons le rôle des institutions dans le pays d'accueil de l'IDE et dans le pays d'origine en estimant une équation gravitationnelle pour le stock d'IDE bilatéral et en incluant un indicateur institutionnel relatif aux deux économies concernées par l'échange (origine et destination). Deuxièmement, nous traitons les problèmes de multicolinéarité et d'endogénéité en comparant systématiquement les résultats des estimations incluant ou non le PIB par habitant parmi les variables explicatives (cette variable étant corrélée avec un certain nombre de mesures de la "qualité" institutionnelle), en procédant à des estimations en deux étapes, et en instrumentant les institutions lorsque cela s'avère nécessaire. Troisièmement, nous étudions en détail les institutions qui comptent en utilisant la base de données Profils Institutionnels mise à disposition par le réseau du ministère français de l'économie et des finances et qui couvre 52 pays pour l'année 2001. Cette base nous permet de déterminer les caractéristiques instutionnelles les plus importantes pour l'IDE. Nous utilisons ensuite des variables proches issues des bases de données institutionnelles classiques afin de confirmer nos résultats. Lorsque c'est possible, une estimation en panel complète l'analyse. Enfin, nous étudions l'impact de la "distance institutionnelle" sur l'IDE bilatéral.

Les résultats montrent que les institutions influent sur l'IDE indépendamment du PIB par habitant. Ils mettent en évidence l'importance de l'efficacité du secteur public au sens large comme déterminant de l'IDE. Ceci comprend en particulier le système fiscal, la facilité à créer une entreprise, l'absence de corruption, la transparence, le droit des contrats, la sécurité des droits de propriété, l'efficacité de la justice et la surveillance prudentielle. Le 
degré de concurrence semble également jouer un rôle, bien que la concentration du capital à la fois dans le pays d'origine et dans le pays de destination de l'IDE ait un impact positif sur l'IDE.

Alors que de "bonnes" institutions dans le pays d'accueil sont toujours favorables à l'IDE, aucun résultat général ne se dégage pour ce qui concerne les institutions du pays d'origine. Enfin, les estimations en panel montrent que la distance institutionnelle tend à réduire l'IDE bilatéral, même si les résultats sont moins clairs dans l'analyse en coupe.

Ces différents résultats sont encourageants au sens où ils montrent que les efforts d'un pays en développement pour améliorer ses institutions et les rapprocher des institutions des pays sources sont susceptibles d'élever les investissements directs étrangers dans ce pays, indépendamment de l'impact indirect via l'élévation du PIB par habitant. Les ordres de grandeur issus des estimations sont importants : un pays qui passerait de la qualité institutionnelle la plus faible à la plus élevée pourrait voir son IDE entrant augmenter autant que s'il devenait soudainement voisin d'un grand pays source d'IDE.

\section{RÉSUMÉ COURT}

Cet article contribue à la littérature sur les déterminants de l'investissement direct étranger dans les économies en développement et reconsidère le rôle de l'environnement institutionnel comme déterminant de l'IDE. On utilise une base de données originale sur les institutions, avec un détail sans précédent sur les caractéristiques institutionnelles de 52 pays, et l'on compare les résultats avec ceux obtenus à l'aide des sources de données classiques. L'analyse économétrique tient compte de la corrélation existant entre la "qualité" institutionnelle et le PIB par habitant, ainsi que de l'endogénéité éventuelle des institutions. On étudie l'impact non seulement des institutions du pays de destination de l'IDE, mais également de celles du pays d'origine et de la "distance institutionnelle" entre l'origine et la destination.

Classification JEL : F23, R3

Mots Clefs : Investissement direct à l'étranger, modèle de gravité, institutions, pays en développement. 


\title{
INSTITUTIONAL DETERMINANTS OF FOREIGN DIRECT INVESTMENT
}

\author{
Agnès BÉNASSY-QUÉRÉ ${ }^{2}$ \\ Maylis COUPET ${ }^{3}$ \\ Thierry MAYER ${ }^{4}$
}

\section{Introduction}

Since the late 1990s, the literature on economic development has been renewed by focusing on the quality of domestic institutions as a key explanation of cross-country differences in both growth rates and income per capita (see IMF, 2003 and Acemoglu et al., 2004, for recent surveys). Efficient protection of civil and property rights, extended economic and political freedom and low level of corruption have been in particular shown to be associated with higher prosperity. In this type of work, the crucial issue is whether good institutions can promote development, or whether it is necessary to attain a certain level of wealth to improve institutions. The reverse causality problem (GDP per capita explaining the level of institutions) has been tackled by instrumenting institutions with geographic variables such as the latitude of the country (Hall and Jones, 1999). Acemoglu, Johnson and Robinson $(2001,2002)$ have provided a complete story behind this sort of instrumentation based on the incentives faced by colonizers to install "good institutions" depending on the prevalence of unknown and dangerous germs in colonized countries. Their story seems to be strongly backed up by the empirical findings, although there are debates about the scope of this relationship (see Rodrik, 2004). As a matter of fact, Kaufmann and Kraay (2002) find that the causality runs from institutions to per capita income rather than the other way round. Simultaneously, there has been a growing interest in the determinants of foreign direct investment (FDI) in developing countries, as FDI is considered one of the most stable component of capital flows to developing countries and can also be a vehicle for technological progress through the use and dissemination of improved production techniques. Not surprisingly, thus, a number of authors have also studied the link between institutions and $\mathrm{FDI}^{5}$.

\footnotetext{
${ }^{2}$ CEPII (corresponding author : a.benassy@cepii.fr).

${ }^{3}$ INSEE

${ }^{4}$ University of Paris-Sud, also affiliated at CEPII, PSE Paris-Jourdan, and CEPR (tmayer@univparis1.fr).

${ }^{5}$ Recent examples are Kinoshina and Campos (2003) and Méon and Sekkat (2004) focusing on transition economies and MENA countries, respectively.
} 
Institutional Determinants of Foreign Direct Investment

Such link could be seen as one channel through which institutions promote productivity growth. Indeed, good institutions are supposed to exert their positive influence on development through the promotion of investment in general, which faces less uncertainty and higher expected rates of return. Because FDI is now a very large share of capital formation in poor countries (UNCTAD, 2004), the FDI-promoting effect of good institutions might be an important channel of their overall effect on growth and development.

There are several reasons why the quality of institutions may matter for attracting FDI. One is rooted on the results of the growth literature : By raising productivity prospects, good governance infrastructures may attract foreign investors. A second reason is that poor institutions can bring additional costs to FDI. This can be the case of corruption for instance (Wei, 2000). A third reason is that, due to high sunk costs, FDI is specially vulnerable to any form of uncertainty, including uncertainty stemming from poor government efficiency, policy reversals, graft or weak enforcement of property rights and of the legal system in general.

An early study by Wheeler and Mody (1992) found the first principal component of 13 risk factors (including bureaucratic red tape, political instability, corruption and the quality of the legal system) to have no significant impact on the location of US foreign affiliates. However the index also included factors like the living environment of expatriates or inequality which are not directly related to the quality of institutions. Later studies by Wei $(1997,2000)$ pointed out corruption as a significant impediment to inward FDI. This result has been challenged by Daude and Stein (2001) who point out the high collinearity between their measure of corruption and GDP per capita, which can lead to spurious results when GDP per capita is not included in the equation. Using a wider range of institution variables, they nevertheless show inward FDI to be significantly influenced by the quality of institutions. More specifically, five out of six governance indicators provided by Kaufman et al. (1999) are shown to matter : Political instability and violence, government effectiveness, regulatory burden, rule of law and graft. Only the voice and accountability indicator appears to be a non significant determinant of FDI. Further regressions, using International Country Risk Guide and La Porta et al. (1998) indicators, show risk of repudiation of contracts by government, risk of expropriation and shareholder rights to matter.

Globerman and Shapiro (1999) argue that the same factors should have an impact on both inward and outward FDI. For instance, good institutions could have a positive impact on FDI outflows because they create favorable conditions for multinational companies to emerge, and hence to invest abroad. Consistently, Globerman and Shapiro (2002) estimate the impact of the first principal component of the six governance indicators constructed by Kaufman et al. (1999) on both inflows and outflows of FDI, the latter variable being an aggregate of all flows from any source country or to any host country. They find good governance to impact positively both on FDI inflows and outflows, although the latter effect is only significant for relatively big and developed countries. One limitation of this study is that the institutional quality of the source country and of the host country cannot be included 
at the same time since the estimations do not rely on bilateral flows. Hence it is not possible to rank the importance of governance in the source country compared to that of the host country. The impact of institutions on FDI has more recently been analyzed within the framework of gravity models where FDI bilateral flows or stocks essentially depend on GDP or population in the source and/or the host country, and on the geographic distance between both countries (Eaton and Tamura, 1994, provide an early application of the gravity model to FDI).

Another advantage of using bilateral data is the examination of the effect of institutional distance between the host and the source country on FDI. Levchenko (2004) suggests that institutional differences may be a source of comparative advantages, some sectors being more "institution-intensive" than others, and that this could be a source of more trade flows. To the extent that multinational firms try to take advantage of comparative advantages, this would likely raise FDI too. On the contrary, Aizenman and Spiegel (2002), by using a principal-agent framework where ex-post monitoring of contracts is more costly for foreign investors than for domestic ones, argue that the share of FDI in total investment should be lower in countries with weak enforcement of property rights. Then, if investors from weak institution countries face lower costs (when investing in weak institution countries) than investors from strong institution countries, this would entail that institutional distance between the origin and the host country should have a negative impact on bilateral FDI. This result meets traditional arguments of the literature on management, which stresses "psychic distance" as a major impediment to the decision of companies to enter foreign markets : "psychic closeness" would reduce either perceived uncertainty or learning costs about the target countries (see Habib and Zurawicki, 2002, for a short review). Finally, if institutions are dependent on economic and social history (including the colonization era), then one could observe more FDI, other things equal, amongst countries displaying relatively similar institutions.

To our knowledge, only Habib and Zurawicki (2002) have to date studied the impact of institutional distance on bilateral FDI. Focusing on corruption, they find that the absolute difference of the corruption index between the investor and the host country has a negative impact on bilateral FDI. This interesting result, based on only one aspect of institutional quality, has remained quite isolated in the literature so far. In order to generalize this type of result, one has to deal with the problem of using an aggregate measure of institutional quality. Indeed, the judgement on institution quality can be subject to debates. One reason comes from the way data on institutions is collected - through local experts, miscellaneous observations or a survey in one host country (often the United States). A second reason is the selection of items to be included in the governance indexes. A third reason is the interpretation to be given to some items like, for instance, the type of law (common law versus civil law) or the extent of labor market regulations. We use a new database with detailed information on a wide variety of institutional characteristics to give the most precise results possible. 
Another limitation of the existing literature concerns multicollinearity and endogeneity. The level of development of a country is a likely determinant of inward FDI, for several reasons pointing in different directions. First, a large difference in GDP per capita between the source country and the host may reflect a difference in factor endowments, hence justify both trade and FDI between the two countries. This first explanation may not be very powerful however since the bulk of FDI in the world happens to flow from high income to high income countries. Second, if multinational firms are mainly interested by market access, then they will be attracted by both the size of the host country and by the purchasing power of its inhabitants. For a given GDP in the host country, a multinational will be happier the higher the GDP per capita because high GDP per capita generally means some ground for product differentiation and higher profits. Finally, GDP per capita is also a measure of productivity and of real wages. To the extent that multinational firms achieve higher productivity than local firms, low GDP per capita will entail low labour costs, which will act as an attraction factor. On the whole, there are many reasons to expect GDP per capita to matter, albeit with an ambiguous sign. Since governance indicators are likely to be correlated to GDP per capita (indeed, this link is one major finding of the recent growth literature surveyed above), multicollinearity becomes an issue. Hence, a finding of a positive impact of governance on FDI could in fact result from the positive impact of GDP per capita. The impact of GDP per capita on inward FDI is theoretically ambiguous. This is because high GDP per capita reflects both high purchasing power of consumers and high real wages. However empirical studies generally show GDP per capita to have a positive, although not always significant, impact on inward FDI. Omitting this variable could hence lead to spurious results. Endogeneity comes from the fact that FDI inflows can be a factor of governance improvement (see Selowski and Martin, 1997). Contrasting with the literature on institutions and growth, the literature on institutions and FDI does not tackle the potential endogeneity bias ${ }^{6}$.

We contribute to the existing literature in several ways. First, we re-examine the role of governance infrastructure in the host and in the source country by estimating a gravity equation for bilateral FDI stocks that includes governance indicators for the two countries. Second, we tackle multicollinearity and endogeneity bias by systematically comparing estimations with and without GDP per capita, by using two-stage estimations, and by instrumenting governance variables when necessary. Third, we look further into the detail of institutions by using a new database constructed by the French Ministry of Finance network in 52 foreign countries. This database is used to point out in some detail the relevant institutional features. Its country coverage, which focuses on developing countries, is very helpful

\footnotetext{
${ }^{6}$ Larrain and Tavares (2004) study the impact of FDI on the extent of corruption. They do so by instrumenting FDI with a gravity model. However geographic distance to large capital exporters may on itself have an impact on corruption, for instance through trade and migrations. The marginal impact of FDI then is not granted.
} 
to study the impact of the institutional environment of the host country. It does not allow however to go deeply into the impact of the institutional environment in the source country as well as into the impact of institutional distance. Hence we complement our analysis with estimations based on the most proximate variables found in other existing databases with a more balanced country coverage between industrial and developing countries. When possible, panel data estimations are also carried out. Finally, we study the impact of institutional distance on bilateral FDI.

The paper is organized as follows. Section 2 presents the simplest benchmark gravity equation on bilateral FDI stocks. Section 3 describes the institutional data used in this study. The impact of the institutional quality of the host country is studied in Section 4. Section 5 explores the impact of the institutional environment of the origin countries and of the institutional distance on bilateral FDI. In Section 6, we turn to alternative databases on institutions in order to confirm our results concerning the impact of the institutional environment of the host country and to further study the impact of the institutional environment of the source. Section 7 concludes.

\section{The basic gravity model on bilateral FDI stocks}

We first present simple gravity estimations of bilateral FDI stocks, which will be considered as our benchmark in the following. We use the OECD database on bilateral stocks of FDI. In terms of country coverage, most observations correspond to FDI originating from each of the different OECD member countries, and located in either OECD countries, or emerging and developing economies. FDI stocks are converted to millions of current US dollars over the 1985-2000 period, and a non negligible portion of observations are zeros (3341 out of a total of 15559 observations). Working on the logarithm of FDI then imposes to drop these observations, with a potential selection bias. Several solutions are possible to circumvent this problem. The first, and perhaps most used, one consists of working with $\ln (a+F D I)$ instead of $\ln (F D I)$, with a relatively small constant $a$. Using $a=1$ allows setting to zero the dependent variable when FDI is zero. However it would substantially compress the distribution of FDI here because of the unit used. We use $a=0.3$, which corresponds to the first decile of the distribution of strictly positive FDI values. The second method to avoid the selection bias is to run the two-step Heckman estimation procedure. We use this second method as a robustness check in unreported regressions. Results (available upon request) are qualitatively similar.

We start by estimating a simple gravity equation where the bilateral FDI stock is explained by the GDPs of both the source $(i)$ and the host country $(j)$, and by a set of transaction costs proxies including in particular the geographic distance between both countries (DIST $T_{i j}$ ) (see Wei, 2000). Although the theoretical foundation of the gravity equation for bilateral FDI is much less clearly established than for trade flows (see Feenstra, 2003, for a broad 
Institutional Determinants of Foreign Direct Investment

overview of the recent advances of theoretical foundations of gravity equations for trade flows), it is still possible to justify this framework in particular for "horizontal" FDI originating from country $i$ and intended to serve the local market of country $j$. As for trade flows, GDP terms are proxies for supply and demand forces. The term $\mathrm{GDP}_{j}$ captures the size of demand to be served by affiliates, while $\mathrm{GDP}_{i}$ is proportional to the pool of potential investors from country $i$. The distance term is intended to account (crudely) for various transaction costs in the bilateral investment.

Here GDPs are taken from the World Bank WDI database (in current USD). The distance variable is calculated as a mean distance between the main towns of each country (source : CEPII databases on bilateral distances, available at www.cepii.fr). These basic variables are complemented with a dummy for contiguity $\left(\mathrm{CONT}_{i j}\right)$ and another one for common language $\left(\mathrm{COMLG}_{i j}\right)$, also from CEPII's databases. Like distance, these two variables account for various transaction costs incurred when investing abroad. GDPs per capita (GDPCAP, measured in PPP) of both the source and the host country are also included in the equation. As discussed by Globerman and Shapiro (2002), the sign of the impact of GDP per capita is ambiguous, since the latter variable both covers the level of development (and purchasing power), which encourages both outward and inward FDI, and the level of wages which can discourage inward FDI if not compensated by productivity. However it is crucial to introduce this variable which is potentially highly correlated with institutions : Omitting it could later lead to spurious conclusions concerning the impact of institutions on FDI. Overall, our baseline equation is the following :

$$
\begin{aligned}
\ln \left(0.3+F D I_{i j}\right) & =a_{0}+a_{1} \ln \left(G D P_{i}\right)+a_{2} \ln \left(G D P_{j}\right)+a_{3} \ln \left(D I S T_{i j}\right) \\
& +a_{4} C O N T_{i j}+a_{5} C O M L G_{i j}+a_{6} \ln \left(G D P C A P_{i}\right) \\
& +a_{7} \ln \left(G D P C A P_{j}\right)+u_{i j}
\end{aligned}
$$

Results are displayed in Table 1. Columns (1) to (4) provide the OLS estimates for pooled data over 1985-1990 (Column 1), 1990-1995 (Column 2) and 1995-1998 (Column 3) as well as cross-section estimates in 1998, last year of the FDI panel with enough observations for developing host countries (Column 4). In the last column of the table a measure of government efficiency is added to the Equation and estimated for year 1998 in order to test for the robustness of all other coefficients. This efficiency variable is one of the often used variable taken from the Fraser Institute database (see below).

The overall fit of each regression is, as usual in this type of estimation, quite high, and much improved in the last period (1995-2000), compared with the first one (1985-1990). This confirms that the gravity model is a good and robust empirical description of international patterns of capital investment. All coefficients are significant at the 5\% level, except the host country GDP per capita in the 1998 estimation. As expected, higher GDPs, lower distance, contiguity and common language all have a positive impact on bilateral FDI. 
Coefficients are quite stable over time, except the one on distance which has a seemingly paradoxical evolution. Indeed, the impact of distance on FDI seems to get more negative over time, which contradicts the intuition that with growing level of liberalization in sectors targeted by FDI and falling communication and travelling costs over that period, space should matter less and less. This result is not isolated however, as it has also been found on trade flows (see Brun et al., 2002, as well as Disdier and Head, 2004). The explanations of such evolutions are still unclear and might result for instance from regionalism, fragmentation in the production process, with newly outsourced stages of production in proximate countries. Finally, the GDP per capita of both the source and the host country have a positive impact on bilateral FDI, although the effect of the host country's GDP per capita is not significant in 1998 (possibly due to the Asian crisis).

Introducing an institutional variable in the equation (the efficiency of public administration in the source country and in the host country) has no impact on the coefficients on both GDPs, on distance and on common language and contiguity dummies. It reduces the impact of GDP per capita in the origin country and reverses the sign on GDP per capita in the host country, likely due to multicolinearity problems (see below). As expected, public efficiency both in the host country and in the source country have a positive and significant impact on bilateral FDI.

\section{Data on institutions}

In the following, we introduce institutional variables in a systematic way in the gravity model presented in Section 2. Several databases on institutions are successively used :

- The Institutional Profiles (IP) database : In 2001, the French Ministry of Finance conducted a detailed survey on institutions through its foreign network in 52 countries (the database is described in detail in Berthelier et al., 2003). A total of 330 elementary questions were asked concerning public institutions, capital markets, goods markets and labor markets. In each case, a set of questions were asked covering political institutions, public order, public governance, market freedom, investment on future, ability to reform, security of transactions and contracts, regulation, openness, and social cohesion. Each question was itself decomposed into elementary, objective items ranked 0 or 1 (weak institutions) to 4 (good institutions). The advantages of this database are the following. First, the respondents are relatively homogenous since all of them are French civil servants working for the foreign Minefi network. Second, the way the variables are constructed, by adding the same elementary items with the same weights, provides relatively objective and comparable synthetic measures of institutions. Finally, the coverage of the database is very large, providing a comprehensive database on various aspects of institutions. However these advantages come along with two drawbacks. First, only one year is available (2001). Second, few developed countries are included in the sample, which reduces the 
TAB. 1 - Bilateral FDI, benchmark regressions and the efficiency of public administration

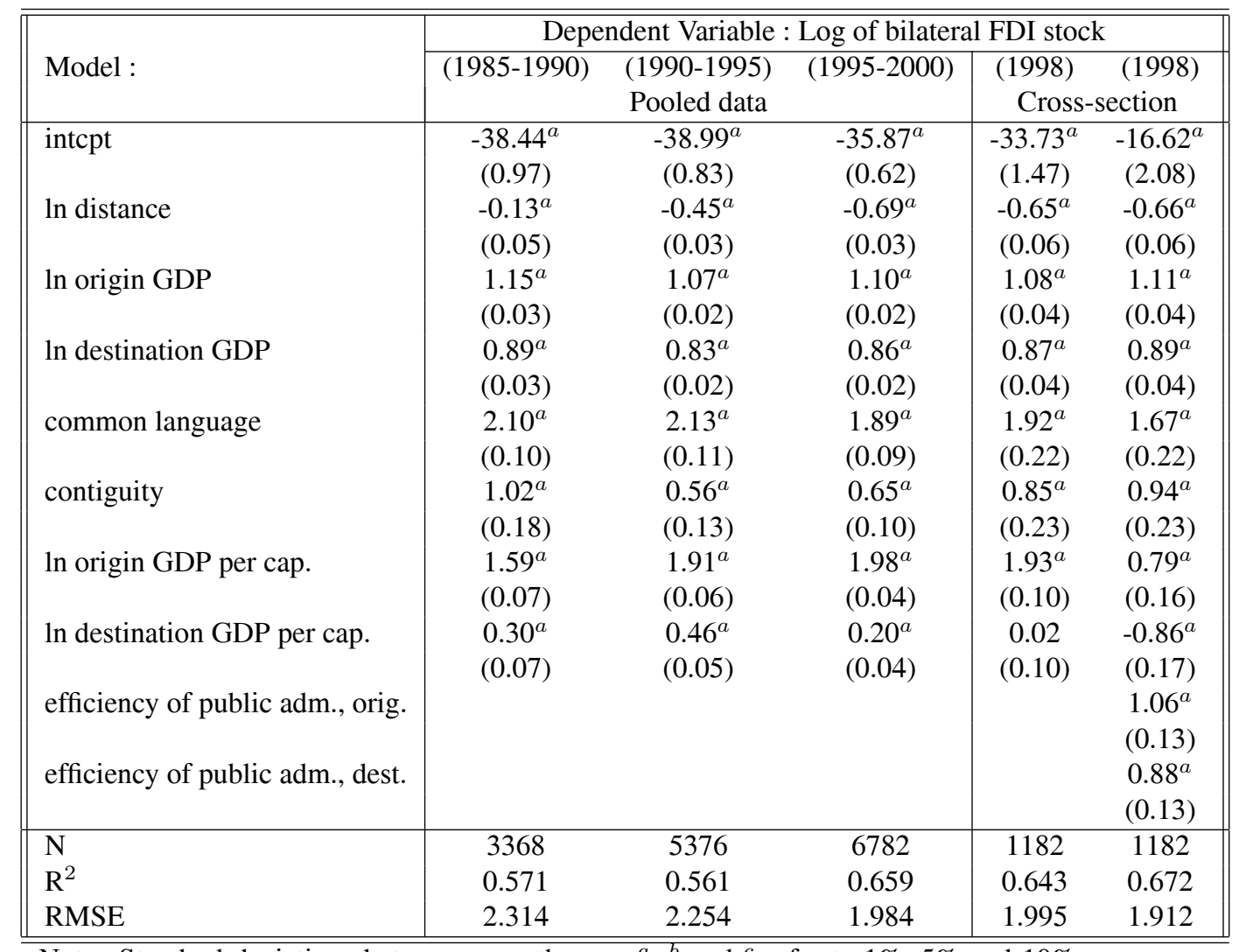

Note : Standard deviations between parentheses : ${ }^{a},{ }^{b}$ and ${ }^{c}$ refer to $1 \%, 5 \%$ and $10 \%$ significance levels respectively. Standard errors are robust to heteroskedasticity. 
scope for studying the impact of the institutional environment of the source country as well as institutional distance between the source and the host.

- The Fraser Institute database : Since 1986, the Fraser Institute has constructed indices of economic freedom based on three key notions : Individual choice and voluntary transaction, free competition, personal and property protection. These notions are then detailed along several aspects of the economy, using miscellaneous sources such as the World Economic Forum Global Competitiveness Report, the PRS Group International Country Risk Guide, or even more classical sources such as the IMF International Financial Statistics. Our motivation for using this database is principally based on its temporal dimension. We use the Fraser database to introduce a time dimension (1985, 1990, 1995, 2000) for some items which are shown to matter in the regressions performed with the IP database.

- The KKZL database : the Kaufmann, Kraay and Zoidon-Lobatón (KKZL) database is widely used in the empirical literature on the impact of institutions on FDI. This database deals with public governance in 178 countries. It compiles data from 13 different organizations. The large country coverage is allowed by the fact that the indicators are estimated rather than directly observed. Another issue with this governance effectiveness index is that it is available for the year 1998 only.

- World Development Indicators (World Bank) : This database covers 154 countries and all years for which we have data on FDI stocks. We use market capitalization (\% of GDP), the share of children aged 10-14 in the labor force, and the R\&D expenses as a share of GDP as additional institutional variables.

One cannot rule out a priori that institutions are endogenous to FDI : Economic openness could well act as a vector of reform in emerging countries, in particular through pressure exerted by newly established affiliates to see institutions reformed in order to improve the business climate. Hence, it may be necessary to instrument institutions. We follow the institutions and growth literature (Mauro, 1995 ; Hall and Jones, 2001 ; Acemoglu et al. 2001) for the choice of instruments. The latitude of the country appears to be a good instrument since it is correlated to most institution variables but should not be a direct factor influencing bilateral FDI. We also use the number of ethnies and the number of religions, which both proxy for the ethno-social fragmentation of the population, with a possible negative impact on institutions suggested by Alesina et al. (1999). Conversely, we do not retain landlockness as an instrument, since it can constitute a direct impediment to inward FDI, through increased export costs for affiliates. We do not retain either the mortality rate of settlers used by Acemoglu et al. (2001) and followers since this variable is specific to former colonies, and would thus reduce our sample. 


\section{The impact of institutions in the host country}

The vast majority of the literature on institutions and FDI focuses on the institutions of the host country : "Bad" institutions are suspected to reduce inward FDI, hence reducing the scope for economic convergence. The IP database is particularly well adapted to study this question since it describes the institutions of host countries in great detail for 52 countries, 45 of which are either emerging or in transition. Hence, the gravity equation is re-estimated with an additional, institutional variable for the host country $\left(\mathrm{INST}_{j}\right)$ :

$$
\begin{aligned}
\ln \left(0.3+F D I_{i j}\right) & =a_{0}+a_{1} \ln \left(G D P_{i}\right)+a_{2} \ln \left(G D P_{j}\right)+a_{3} \ln \left(D I S T_{i j}\right) \\
& +a_{4} C O N T_{i j}+a_{5} C O M L G_{i j}+a_{6} \ln \left(G D P C A P_{i}\right) \\
& +a_{7} \ln \left(G D P C A P_{j}\right)+a_{8} I N S T_{j}+u_{i j}
\end{aligned}
$$

Estimations are performed for the most recent year that covers a large set of countries (1998). Our procedure introduces 75 institution variables from the IP database successively. Because institution variables are often correlated with one another, it is generally not possible to include several institutions in the same equation. Another possibility would have been to aggregate all institution variables into their first principal component for instance. However this would have implied assuming substitutability between institution variables which belong to very different areas. We limited the extent of substitutability by working at the semi-detailed level, i.e. with 75 variables aggregated from a few homogenous items in the IP database (three-digit level). This choice allows us to look at the ranking of institutional characteristics according to their role in attracting FDI.

The results for successive institution variables are ranked according to their contribution in explaining the variance of the explained variable (i.e. of bilateral FDI stocks). Table 2 reports the results for the twenty best fits, ranging from 0.716 to 0.728 as compared to 0.643 found in the regression without institution variable (Table 1, Column (4)). The coefficient for the institution variable is reported together with the one on GDP per capita which is likely to be correlated to some institution variables. The correlation between GDP per capita and each institution variable is also reported on the same row.

All institution variables are constructed so that a rise in the variable signals an "improvement in the institutions". All coefficients but two bear a significantly positive sign, meaning that a rise in "institutional quality" in the host country attracts FDI. In two cases the coefficient is negative : Lower concentration of capital, and the existence and enforcement of labor laws tend to reduce the amounts of FDI received. The former effect could be related to increased competition (hence lower profit rates) when capital is less concentrated. However this interpretation is contradicted by the positive sign on the "competition - production sector" variable. More likely, the negative impact of a weak concentration of capital, hence the 
positive impact of capital concentration, could be linked to agglomeration forces (multinational firms are more likely to invest in a country when they have already heavily invested in the past), and to the existence of public monopolies to be privatized. The effect of labor laws can be interpreted as the detrimental impact of such laws on labor flexibility and cost. All other variables bear a positive sign. In particular, the results highlight the role of (i) the quality of information and of human capital, (ii) the efficiency of public administration (including tax systems and easiness to create a company, lack of corruption, contract law, security of property rights, prudential standards) and (iii) the extent of competition in all sectors. It is interesting to note the importance of institutions of the financial sector where competition, information and regulations seem to go hand with hand. The security of contracts and of property rights also seem to play a positive role.

ТАВ. 2 - The role of institutions in the host country

\begin{tabular}{|c|c|c|c|c|}
\hline \multirow[b]{2}{*}{ Institutions : } & \multicolumn{4}{|c|}{ Dependent Variable $: \ln \left(0,3+F D I_{i j}\right)$} \\
\hline & GDP per cap. & host institution & R2a & corr. \\
\hline Weak concentration of capital & $\begin{array}{c}0.218^{b} \\
(0.104)\end{array}$ & $\begin{array}{l}-0.869^{a} \\
(0.122)\end{array}$ & 0.728 & -0.027 \\
\hline Existence and enforcement of labor laws & $\begin{array}{l}0.758^{b} \\
(0.136)\end{array}$ & $\begin{array}{l}-0.621^{a} \\
(0.101)\end{array}$ & 0.725 & 0.615 \\
\hline Competition - production sector & $\begin{array}{c}0.016 \\
(0.111)\end{array}$ & $\begin{array}{l}0.586^{a} \\
(0.12)\end{array}$ & 0.721 & 0.259 \\
\hline Security of formal property rights & $\begin{array}{l}-0.456^{b} \\
(0.174)\end{array}$ & $\begin{array}{c}0.752^{a} \\
(0.148)\end{array}$ & 0.721 & 0.759 \\
\hline Support to R\&D and innovation & $\begin{array}{l}-0.134 \\
(0.128)\end{array}$ & $\begin{array}{l}0.452^{a} \\
(0.09)\end{array}$ & 0.72 & 0.611 \\
\hline Information on firms & $\begin{array}{l}-0.281^{b} \\
(0.156)\end{array}$ & $\begin{array}{l}0.486^{a} \\
(0.103)\end{array}$ & 0.719 & 0.645 \\
\hline Ability of bank executives & $\begin{array}{l}-0.187 \\
(0.147)\end{array}$ & $\begin{array}{l}0.479^{a} \\
(0.104)\end{array}$ & 0.719 & 0.620 \\
\hline Internal control of banks & $\begin{array}{c}0.002 \\
(0.125)\end{array}$ & $\begin{array}{l}0.372^{a} \\
(0.088)\end{array}$ & 0.718 & 0.352 \\
\hline Individual incentive to tertiary education & $\begin{array}{c}0.052 \\
(0.117)\end{array}$ & $\begin{array}{c}0.32^{a} \\
(0.071)\end{array}$ & 0.718 & 0.359 \\
\hline Government efficiency - evolution & $\begin{array}{l}-0.161 \\
(0.136)\end{array}$ & $\begin{array}{l}0.552^{a} \\
(0.122)\end{array}$ & 0.718 & 0.667 \\
\hline Easiness to enter a market & $\begin{array}{c}-0.18 \\
(0.141)\end{array}$ & $\begin{array}{l}0.507^{a} \\
(0.111)\end{array}$ & 0.718 & 0.535 \\
\hline Info. on the quality of goods and services & $\begin{array}{l}-0.027 \\
(0.125)\end{array}$ & $\begin{array}{l}0.336^{a} \\
(0.08)\end{array}$ & 0.718 & 0.549 \\
\hline & next page & & & \\
\hline
\end{tabular}




\begin{tabular}{||l|cccc||}
\hline \hline \multicolumn{5}{|c||}{ continued } \\
\multicolumn{4}{|c||}{ Dependent Variable $: \ln \left(0,3+F D I_{i j}\right)$} \\
\cline { 2 - 5 } Institutions : & GDP per cap. & host institution & R2a & corr. \\
\hline Competition - distribution & 0.023 & $0.306^{a}$ & 0.718 & 0.304 \\
Efficiency of the tax system & $(0.122)$ & $(0.074)$ & & \\
& -0.254 & $0.467^{a}$ & 0.717 & 0.75 \\
Lack of corruption & $(0.158)$ & $(0.111)$ & & \\
Easiness to create a company & $-0.297^{b}$ & $0.442^{a}$ & 0.717 & 0.757 \\
& $(0.163)$ & $(0.102)$ & & \\
Info. required for issuing bonds & -0.016 & $0.343^{a}$ & 0.717 & 0.432 \\
Contract law & $(0.128)$ & $(0.085)$ & & \\
& 0.000 & $0.363^{a}$ & 0.716 & 0.602 \\
$\Delta$ local / international prudential standards & $(0.126)$ & $(0.1)$ & & \\
& 0.122 & $0.38^{a}$ & 0.716 & 0.371 \\
Competition - banks & $(0.115)$ & $(0.1)$ & & \\
& 0.065 & $0.322^{a}$ & 0.716 & 0.494 \\
& $(0.12)$ & $(0.092)$ & & \\
\hline \hline
\end{tabular}

Note : Each line shows the coefficients on GDP per capita and on the institutional variable considered in the regression described by (2). Each institutional variable is instrumented by latitudes, number of religions and ethnic groups of considered countries. Standard deviations under parentheses $;{ }^{a},{ }^{b}$ and ${ }^{c} 1 \%, 5 \%$ and $10 \%$ significance level respectively. Standard deviations account for correlations among errors for each host country.

However, these first results can potentially suffer from a multicolinearity problem. Indeed, as appears in the last column of Table 2, most institution variables are positively correlated to GDP per capita, with a correlation coefficient sometimes above $60 \%$. This feature may explain why the coefficient on GDP per capita is sometimes negative and/or non significant. In order to tackle this problem, two sets of two-stage estimations are successively performed. First, we replace $\operatorname{INST}_{j}$ in Equation 2 by the residual of the following estimation :

$$
I N S T_{j}=a_{1}+b \ln \left(G D P C A P_{j}\right)+u_{j}
$$

The residual $u_{j}$ can be interpreted as the part of the institution that does not stem from the living standard of the country. Hence the coefficient on $u_{j}$ replacing INST ${ }_{j}$ in Equation 2 will be interpreted as the impact of the corresponding institution of the host on the top of the impact of GDP per capita.

The second two-step regression consists in replacing $\ln \left(\mathrm{GDPCAP}_{j}\right)$ in Equation 2 by the residual $v_{j}$ of the following estimation :

$$
\ln \left(G D P C A P_{j}\right)=a_{2}+c I N S T_{j}+v_{j}
$$


In turn, the residual $v_{j}$ can be interpreted as the part of GDP per capita that does not stem from institutions. Hence, the coefficient on $v_{j}$ replacing $\ln \left(\mathrm{GDPCAP}_{j}\right)$ in Equation 2 can be interpreted as the impact of an increase in GDP per capita holding the quality of institutions constant.

Note that the two experiments are performed one after the other. Results are displayed in Table 3 for the thirty institutional variables displaying the highest correlation with GDP per capita (between 55 and 85\%). The impact of those institutional variables in the baseline estimation is reminded in Column (2), the impact of GDP per capita being displayed in Column (1). Column (3) reports the correlation coefficient between GDP per capita and the corresponding institutional variable. Column (4), labeled GDP per cap.2, presents the impact of GDP per capita when orthogonalized to the corresponding institution through Equation 4. Strikingly, the coefficient of GDP per capita is now always positive and almost always significant at the 5\% level. By construction, the coefficients on institutions in these regressions are the same as in the baseline case.

The results for orthogonalized institutions (through Equation 3) are displayed in Column (5) labeled host inst.1. They are almost always positive and significant at the $1 \%$ level. The only exception is the negative impact of labor laws, as in the baseline estimation. Capital concentration does not show up in this table because of low correlation with GDP per capita. Finally, the last columns, labeled "inst. sign." summarizes the significance of each institution variable in the baseline ( $\mathrm{H}$ for high, $\mathrm{L}$ for low) and in the two-stage estimation (same code).

Most variables that were significant in the baseline estimation remain so in the two-stage one. Only two variables switch from $\mathrm{H}$ to L. These are "technological environment" and "regional income discrepancies". Conversely, some variables that were not significant in the baseline become significant in the two-step one. These new variables confirm the role of justice (efficiency of justice, security of contracts and of property rights) and of government efficiency (strategic view, transparency).

We conclude that the quality of some institutions in the host country has a sizeable impact on inward FDI even when the direct and indirect impact of GDP per capita is accounted for : Institutions exert an independent role which is often quite large economically. This is an encouraging result in the sense that independent (i.e. independent from GDP per capita) improvements in institutions should attract FDI and could therefore provide a basis for growth and development. For instance, comparing a host country $k$ with a very low level of protection of property rights (a level of 1 ) to a country $j$ with the highest level, coded $4, j$ is estimated to receive $\exp (3 \times 0.421)=3.53$ times more FDI stock from country $i$ (the transformed dependent variable, $0.3+F D I_{i j}$, more precisely ${ }^{7}$ ) than country $k$. The effect of this extreme improvement in institutions is thus quantitatively large. Turning back to Column (4) of Table 1, contiguity only multiplies the dependent variable by 2.34 , and

\footnotetext{
${ }^{7}$ The exact relationship between the two stocks is $F D I_{i j}=0.759+3.53 F D I_{i k}$.
} 
with a coefficient of 0.87 on host country GDP, the size of the host country needs to be multiplied by slightly more than 4 to generate the same effect as the above institutional drastic improvement. In our sample, the standard deviation of this same variable is 0.76 , which means that a one standard deviation improvement in the protection of property rights increases overall received FDI stock by $\exp (0.76 \times 0.421)-1=37 \%$, still a substantial figure.

TAB. 3 - Two-stage estimations

\begin{tabular}{|c|c|c|c|c|c|c|}
\hline \multirow[b]{3}{*}{ Institutions : } & \multicolumn{6}{|c|}{ "Dependent Variable $: \ln \left(0,3+F D I_{i j}\right)$} \\
\hline & \multicolumn{2}{|c|}{ baseline coefs. } & & \multicolumn{3}{|c|}{ second-step coefs. } \\
\hline & GDP/cap. & host inst. & corr. & GDP/cap.2 & host inst1. & instit. sign. \\
\hline Existence/enforcement of labor laws & $\begin{array}{l}0,758^{b} \\
(0,136)\end{array}$ & $\begin{array}{c}-0,621^{a} \\
(0,101)\end{array}$ & 0,615 & $\begin{array}{l}0,211^{b} \\
(0,103)\end{array}$ & $\begin{array}{c}-0,233^{a} \\
(0,077)\end{array}$ & $\mathrm{HH}$ \\
\hline Security of formal property rights & $\begin{array}{c}-0,456^{b} \\
(0,174)\end{array}$ & $\begin{array}{l}0,752^{a} \\
(0,148)\end{array}$ & 0,759 & $\begin{array}{l}0,205^{b} \\
(0,108)\end{array}$ & $\begin{array}{l}0,421^{a} \\
(0,093)\end{array}$ & $\mathrm{HH}$ \\
\hline Support to R\&D and innovation & $\begin{array}{c}-0,134 \\
(0,128)\end{array}$ & $\begin{array}{c}0,452^{a} \\
(0,09)\end{array}$ & 0,611 & $\begin{array}{l}0,303^{b} \\
(0,108)\end{array}$ & $\begin{array}{c}0,39^{a} \\
(0,075)\end{array}$ & $\mathrm{HH}$ \\
\hline Information on firms & $\begin{array}{l}-0,281^{b} \\
(0,156)\end{array}$ & $\begin{array}{l}0,486^{a} \\
(0,103)\end{array}$ & 0,645 & $\begin{array}{c}0,166 \\
(0,108)\end{array}$ & $\begin{array}{l}0,353^{a} \\
(0,071)\end{array}$ & $\mathrm{HH}$ \\
\hline Ability of bank executives & $\begin{array}{c}-0,187 \\
(0,147)\end{array}$ & $\begin{array}{l}0,479^{a} \\
(0,104)\end{array}$ & 0,62 & $\begin{array}{l}0,215^{b} \\
(0,112)\end{array}$ & $\begin{array}{c}0,381^{a} \\
(0,08)\end{array}$ & $\mathrm{HH}$ \\
\hline Government efficiency - evolution & $\begin{array}{c}-0,161 \\
(0,136)\end{array}$ & $\begin{array}{l}0,552^{a} \\
(0,122)\end{array}$ & 0,667 & $\begin{array}{l}0,272^{b} \\
(0,108)\end{array}$ & $\begin{array}{l}0,449^{a} \\
(0,097)\end{array}$ & $\mathrm{HH}$ \\
\hline Efficiency of the tax system & $\begin{array}{c}-0,254 \\
(0,158)\end{array}$ & $\begin{array}{l}0,467^{a} \\
(0,111)\end{array}$ & 0,75 & $\begin{array}{c}0,26^{b} \\
(0,107)\end{array}$ & $\begin{array}{l}0,323^{a} \\
(0,076)\end{array}$ & $\mathrm{HH}$ \\
\hline Lack of corruption & $\begin{array}{c}-0,297^{b} \\
(0,163)\end{array}$ & $\begin{array}{l}0,442^{a} \\
(0,102)\end{array}$ & 0,757 & $\begin{array}{l}0,231^{b} \\
(0,108)\end{array}$ & $\begin{array}{l}0,281^{a} \\
(0,069)\end{array}$ & $\mathrm{HH}$ \\
\hline Information requirements for issuing bonds & $\begin{array}{c}0 \\
(0,126)\end{array}$ & $\begin{array}{c}0,363^{a} \\
(0,1)\end{array}$ & 0,602 & $\begin{array}{c}0,273^{b} \\
(0,11)\end{array}$ & $\begin{array}{l}0,363^{a} \\
(0,087)\end{array}$ & $\mathrm{HH}$ \\
\hline Bank and financial supervision & $\begin{array}{l}-0,126 \\
(0,142)\end{array}$ & $\begin{array}{l}0,393^{a} \\
(0,107)\end{array}$ & 0,646 & $\begin{array}{l}0,203^{b} \\
(0,108)\end{array}$ & $\begin{array}{l}0,324^{a} \\
(0,082)\end{array}$ & $\mathrm{HH}$ \\
\hline Social mobility - recruitment and promotion & $\begin{array}{l}-0,058 \\
(0,139)\end{array}$ & $\begin{array}{l}0,435^{a} \\
(0,125)\end{array}$ & 0,649 & $\begin{array}{l}0,257^{b} \\
(0,109)\end{array}$ & $\begin{array}{l}0,399^{a} \\
(0,098)\end{array}$ & $\mathrm{HH}$ \\
\hline Guarantee of bank lending (mortgage,...) & $\begin{array}{l}-0,045 \\
(0,136)\end{array}$ & $\begin{array}{l}0,306^{a} \\
(0,089)\end{array}$ & 0,625 & $\begin{array}{l}0,24^{b} \\
(0,11)\end{array}$ & $\begin{array}{l}0,285^{a} \\
(0,073)\end{array}$ & $\mathrm{HH}$ \\
\hline Bankruptcy law & $\begin{array}{c}-0,056 \\
(0,142)\end{array}$ & $\begin{array}{c}0,32^{a} \\
(0,097)\end{array}$ & 0,661 & $\begin{array}{c}0,244^{b} \\
(0,11)\end{array}$ & $\begin{array}{l}0,293^{a} \\
(0,076)\end{array}$ & $\mathrm{HH}$ \\
\hline Denunciation of contracts by the government & $\begin{array}{c}-0,057 \\
(0,15)\end{array}$ & $\begin{array}{l}0,416^{a} \\
(0,146)\end{array}$ & 0,647 & $\begin{array}{c}0,237^{b} \\
(0,107)\end{array}$ & $\begin{array}{l}0,377^{a} \\
(0,104)\end{array}$ & $\mathrm{HH}$ \\
\hline Venture capital & $\begin{array}{c}0,037 \\
(0,125)\end{array}$ & $\begin{array}{c}0,19^{a} \\
(0,062)\end{array}$ & 0,597 & $\begin{array}{c}0,271^{b} \\
(0,11)\end{array}$ & $\begin{array}{l}0,202^{a} \\
(0,055)\end{array}$ & $\mathrm{HH}$ \\
\hline Technological environment & $\begin{array}{l}0,735^{b} \\
(0,189)\end{array}$ & $\begin{array}{c}-0,49^{a} \\
(0,16)\end{array}$ & 0,813 & $\begin{array}{l}0,244^{b} \\
(0,108)\end{array}$ & $\begin{array}{c}0,055 \\
(0,092)\end{array}$ & HL \\
\hline Formal property rights & $\begin{array}{c}-0,038 \\
(0,156)\end{array}$ & $\begin{array}{l}0,251^{a} \\
(0,101)\end{array}$ & 0,739 & $\begin{array}{l}0,265^{b} \\
(0,109)\end{array}$ & $\begin{array}{c}0,232^{a} \\
(0,07)\end{array}$ & $\mathrm{HH}$ \\
\hline Regional income discrepancies & $\begin{array}{l}0,423^{b} \\
(0,134)\end{array}$ & $\begin{array}{c}-0,251^{a} \\
(0,123)\end{array}$ & 0,552 & $\begin{array}{c}0,25^{b} \\
(0,107)\end{array}$ & $\begin{array}{c}0,007 \\
(0,098)\end{array}$ & HL \\
\hline
\end{tabular}


CEPII, Working Paper No 2005-05.

\begin{tabular}{|c|c|c|c|c|c|c|}
\hline \multicolumn{7}{|c|}{ continued } \\
\hline \multirow[b]{3}{*}{ Institutions : } & \multicolumn{6}{|c|}{ Dependent Variable $: \ln \left(0,3+F D I_{i j}\right)$} \\
\hline & \multicolumn{2}{|c|}{ baseline coefs. } & & \multicolumn{3}{|c|}{ second-step coefs. } \\
\hline & GDP/cap. & host inst. & corr. & GDP/cap2. & host inst1. & instit. sign. \\
\hline Ability of the society to adapt and innovate & $\begin{array}{c}0,089 \\
(0,133)\end{array}$ & $\begin{array}{r}0,232^{b} \\
(0,12)\end{array}$ & 0,58 & $\begin{array}{c}0,24^{b} \\
(0,108)\end{array}$ & $\begin{array}{l}0,283^{a} \\
(0,097)\end{array}$ & LH \\
\hline Strategic view by public authorities & $\begin{array}{c}0,123 \\
(0,124)\end{array}$ & $\begin{array}{c}0,193^{b} \\
(0,109)\end{array}$ & 0,577 & $\begin{array}{c}0,26^{b} \\
(0,107)\end{array}$ & $\begin{array}{l}0,265^{a} \\
(0,095)\end{array}$ & LH \\
\hline Transparency of economic administration & $\begin{array}{c}0,037 \\
(0,186)\end{array}$ & $\begin{array}{c}0,218 \\
(0,152)\end{array}$ & 0,769 & $\begin{array}{l}0,254^{b} \\
(0,109)\end{array}$ & $\begin{array}{l}0,242^{a} \\
(0,089)\end{array}$ & LH \\
\hline Access of SMEs to bank lending & $\begin{array}{c}0,104 \\
(0,147)\end{array}$ & $\begin{array}{c}0,149 \\
(0,101)\end{array}$ & 0,696 & $\begin{array}{l}0,255^{b} \\
(0,109)\end{array}$ & $\begin{array}{l}0,206^{a} \\
(0,076)\end{array}$ & LH \\
\hline Efficiency of corportate justice & $\begin{array}{c}0,146 \\
(0,139)\end{array}$ & $\begin{array}{c}0,124 \\
(0,096)\end{array}$ & 0,723 & $\begin{array}{c}0,273^{b} \\
(0,11)\end{array}$ & $\begin{array}{l}0,198^{a} \\
(0,076)\end{array}$ & LH \\
\hline Efficiency of non corporate justice & $\begin{array}{c}0,12 \\
(0,155)\end{array}$ & $\begin{array}{c}0,145 \\
(0,116)\end{array}$ & 0,724 & $\begin{array}{l}0,262^{b} \\
(0,109)\end{array}$ & $\begin{array}{l}0,218^{a} \\
(0,083)\end{array}$ & LH \\
\hline Regulation of competition & $\begin{array}{c}0,166 \\
(0,138)\end{array}$ & $\begin{array}{c}0,1 \\
(0,098)\end{array}$ & 0,572 & $\begin{array}{l}0,251^{b} \\
(0,109)\end{array}$ & $\begin{array}{l}0,167^{a} \\
(0,077)\end{array}$ & LH \\
\hline Vocational training of adults & $\begin{array}{c}0,346^{b} \\
(0,14)\end{array}$ & $\begin{array}{c}-0,094 \\
(0,104)\end{array}$ & 0,591 & $\begin{array}{l}0,261^{b} \\
(0,108)\end{array}$ & $\begin{array}{l}0,083 \\
(0,08)\end{array}$ & LL \\
\hline Respect of intellectual property & $\begin{array}{c}0,115 \\
(0,187)\end{array}$ & $\begin{array}{c}0,11 \\
(0,123)\end{array}$ & 0,845 & $\begin{array}{l}0,263^{b} \\
(0,108)\end{array}$ & $\begin{array}{l}0,173^{a} \\
(0,071)\end{array}$ & LH \\
\hline Weak role of children at work & $\begin{array}{c}0,358^{b} \\
(0,16)\end{array}$ & $\begin{array}{c}-0,103 \\
(0,121)\end{array}$ & 0,726 & $\begin{array}{l}0,266^{b} \\
(0,109)\end{array}$ & $\begin{array}{c}0,105 \\
(0,082)\end{array}$ & LL \\
\hline Transparency of economic policy & $\begin{array}{c}0,32^{b} \\
(0,131)\end{array}$ & $\begin{array}{c}-0,083 \\
(0,105)\end{array}$ & 0,552 & $\begin{array}{c}0,253^{b} \\
(0,109)\end{array}$ & $\begin{array}{c}0,095 \\
(0,088)\end{array}$ & LL \\
\hline Security of private contracts & $\begin{array}{c}0,148 \\
(0,191)\end{array}$ & $\begin{array}{c}0,118 \\
(0,172)\end{array}$ & 0,806 & $\begin{array}{l}0,259^{b} \\
(0,108)\end{array}$ & $\begin{array}{l}0,236^{a} \\
(0,098)\end{array}$ & LH \\
\hline
\end{tabular}

Note : Standard deviations under parentheses ; ${ }^{a},{ }^{b}$ and ${ }^{c} 1 \%, 5 \%$ and $10 \%$ significance level respectively. Standard deviations account for error correlations for each host.

\section{Institutional distance}

Following Globerman and Shapiro (1999), we now investigate the impact of institutions in the source country. As mentioned in the introduction, we are able to compare the impact of the institutions of the source country to those of the host country because we use bilateral FDI data. Furthermore, we are interested in the impact of institutional distance between the source and the host countries. Indeed, the literature on gravity models of trade and FDI use geographic distance as a proxy for transportation and communication costs, but also for cultural, informational or administrative costs. We feel that calculating an institutional distance could help disentangling this second type of costs from transportation and communication costs.

Hence the following equation is estimated : 


$$
\begin{aligned}
\ln \left(0.3+F D I_{i j}\right) & =a_{0}+a_{1} \ln \left(G D P_{i}\right)+a_{2} \ln \left(G D P_{j}\right)+a_{3} \ln \left(D I S T_{i j}\right) \\
& +a_{4} C O N T_{i j}+a_{5} C O M L G_{i j}+a_{6} \ln \left(G D P C A P_{i}\right) \\
& +a_{7} \ln \left(G D P C A P_{j}\right)+a_{8} I N S T_{j}+a_{9} I N S T_{i} \\
& +a_{10} D I N S T_{i j}+u_{i j}
\end{aligned}
$$

where $\left(\operatorname{INST}_{i}\right)$ stands for the institution variable of the investor country and (DINST $i j$ ) is a measure of the institutional distance between the investor and the host, taken as the absolute difference between (INST $i$ ) and (INST ${ }_{j}$ ). Results are presented in Table 4 for the twenty institution variables providing the best fit. Note that including institutional variables for the origin and institutional distance does not alter the results already obtained in Table 2, i.e. with the institutional variables for the host country only. Government efficiency, efficiency of the tax system, support to R\&D, security of formal property rights, ability of bank executives, venture capital and social mobility have a positive and significant impact both for the origin and for the host country, confirming Globerman and Shapiro's (1999) results. However other variables are significant but of opposite signs for the origin and the host, with a higher "quality" of institutions in the origin country reducing outward FDI. This is the case for enforcement of bankruptcy law, information on the quality of goods and services, competition in the distribution sector, insurance and pension funds, individual incentive to tertiary education. For these variables, higher values in the host country attracts more FDI, but higher values in the origin country reduces the flow. Finally, it should be noted that the two variables that have negative, significant signs for the host (weak concentration of capital, existence and enforcement of labor laws) also display a negative, significant sign for the origin country. Overall, most institutional variables have a significant impact on bilateral FDI whether they concern the host or the origin country; most coefficients on the host are positive, but there is no general rule as for the sign of coefficients on origin country variables.

The results on distance are puzzling in the sense that, when significant, higher distance generally seems to raise rather than reduce bilateral FDI. We checked that this result does not come from multicolinearity : The institutional distance is weakly correlated to both institution variables, and additional regressions with only institutional distance (i.e. dropping the source and the host distance institutions) show the same positive coefficients for the same specific institutions. There is no identification problem either, since regressing the distance variable on either the origin or the host institution leads to a very low $R^{2}$. Nevertheless, one must keep in mind that there are much less source countries than host countries in the IP database, which focuses on emerging countries, and no time dimension in the data. Those potential sources of bias are addressed in the remainder of the paper using Fraser institute data. 
TAB. 4 - The impact of institutions : origin country, host country and distance

\begin{tabular}{|c|c|c|c|c|}
\hline \multirow[b]{2}{*}{ Institutions : } & \multicolumn{4}{|c|}{ Dependent Variable $: \ln \left(0,3+F D I_{i j}\right)$} \\
\hline & origin & destination & distance & $\mathrm{R}^{2} \mathrm{a}$ \\
\hline \multirow{2}{*}{ Government efficiency-evolution } & $0.35^{a}$ & $0.627^{a}$ & $0.33^{a}$ & 0.732 \\
\hline & $(0.166)$ & $(0.165)$ & $(0.133)$ & \\
\hline Efficiency of the tax system & $\begin{array}{l}0.429^{a} \\
(0.176)\end{array}$ & $\begin{array}{c}0.527^{a} \\
(0.151)\end{array}$ & $\begin{array}{c}0.021 \\
(0.129)\end{array}$ & 0.727 \\
\hline Support to R\&D and innovation & $\begin{array}{l}0.599^{a} \\
(0.151)\end{array}$ & $\begin{array}{c}0.472^{a} \\
(0.119)\end{array}$ & $\begin{array}{c}0.088 \\
(0.117)\end{array}$ & 0.736 \\
\hline Parents' investment in education & $\begin{array}{c}0.882^{a} \\
(0.152)\end{array}$ & $\begin{array}{c}0.21 \\
(0.156)\end{array}$ & $\begin{array}{c}0.426^{a} \\
(0.14)\end{array}$ & 0.734 \\
\hline Security of formal property rights & $\begin{array}{c}0.543^{a} \\
(0.221)\end{array}$ & $\begin{array}{l}0.911^{a} \\
(0.213)\end{array}$ & $\begin{array}{c}0.253 \\
(0.183)\end{array}$ & 0.731 \\
\hline Contract law & $\begin{array}{c}0.039 \\
(0.161)\end{array}$ & $\begin{array}{c}0.672^{a} \\
(0.177)\end{array}$ & $\begin{array}{l}0.483^{a} \\
(0.181)\end{array}$ & 0.73 \\
\hline Enforcement of bankruptcy law & $\begin{array}{r}-0.399^{a} \\
(0.119)\end{array}$ & $\begin{array}{c}0.299^{a} \\
(0.116)\end{array}$ & $\begin{array}{l}-0.132 \\
(0.127)\end{array}$ & 0.729 \\
\hline Weak concentration of capital & $\begin{array}{c}0.068 \\
(0.183)\end{array}$ & $\begin{array}{c}-0.861^{a} \\
(0.172)\end{array}$ & $\begin{array}{l}-0.286^{b} \\
(0.153)\end{array}$ & 0.738 \\
\hline Information on firms & $\begin{array}{c}-0.03 \\
(0.136)\end{array}$ & $\begin{array}{c}0.59^{a} \\
(0.144)\end{array}$ & $\begin{array}{c}0.132 \\
(0.119)\end{array}$ & 0.729 \\
\hline Information on the quality of goods and services & $\begin{array}{c}-0.179^{b} \\
(0.103)\end{array}$ & $\begin{array}{c}0.372^{a} \\
(0.119)\end{array}$ & $\begin{array}{c}0.231^{a} \\
(0.11)\end{array}$ & 0.73 \\
\hline Competition - production sector & $\begin{array}{c}0.26 \\
(0.171)\end{array}$ & $\begin{array}{l}0.633^{a} \\
(0.159)\end{array}$ & $\begin{array}{c}0.168 \\
(0.162)\end{array}$ & 0.728 \\
\hline Competition - distribution & $\begin{array}{r}-0.558^{a} \\
(0.098)\end{array}$ & $\begin{array}{l}0.234^{a} \\
(0.103)\end{array}$ & $\begin{array}{c}-0.292^{a} \\
(0.098)\end{array}$ & 0.742 \\
\hline Ability of bank executives & $\begin{array}{c}0.243^{b} \\
(0.147)\end{array}$ & $\begin{array}{l}0.723^{a} \\
(0.151)\end{array}$ & $\begin{array}{l}0.392^{a} \\
(0.122)\end{array}$ & 0.736 \\
\hline Venture capital & $\begin{array}{l}0.287^{a} \\
(0.094)\end{array}$ & $\begin{array}{l}0.363^{a} \\
(0.089)\end{array}$ & $\begin{array}{l}0.202^{a} \\
(0.085)\end{array}$ & 0.734 \\
\hline Extension of insurance and pension fund sector & $\begin{array}{c}-0.362^{a} \\
(0.1)\end{array}$ & $\begin{array}{c}0.24^{a} \\
(0.101)\end{array}$ & $\begin{array}{l}-0.062 \\
(0.109)\end{array}$ & 0.728 \\
\hline Traditional credit systems & $\begin{array}{c}0.777^{a} \\
(0.138)\end{array}$ & $\begin{array}{c}0.094 \\
(0.081)\end{array}$ & $\begin{array}{l}0.463^{a} \\
(0.144)\end{array}$ & 0.74 \\
\hline Internal control of banks & $\begin{array}{l}-0.115 \\
(0.119)\end{array}$ & $\begin{array}{c}0.46^{a} \\
(0.134)\end{array}$ & $\begin{array}{c}0.068 \\
(0.135)\end{array}$ & 0.728 \\
\hline Existence and enforcement of labor laws & $\begin{array}{c}-0.423^{a} \\
(0.146)\end{array}$ & $\begin{array}{c}-0.678^{a} \\
(0.148)\end{array}$ & $\begin{array}{l}-0.001 \\
(0.083)\end{array}$ & 0.735 \\
\hline & page & & & \\
\hline
\end{tabular}




\begin{tabular}{||l|cccc||}
\hline \hline \multicolumn{5}{|c||}{ continued } \\
\hline \multirow{3}{*}{ Institutions : } & \multicolumn{4}{|c||}{ Dependent Variable $: \ln \left(0,3+F D I_{i j}\right)$} \\
\cline { 2 - 5 } & origin & destination & distance & $\mathrm{R}^{2} \mathrm{a}$ \\
\hline Social mobility - recruitment and promotion & $0.362^{a}$ & $0.638^{a}$ & $0.258^{b}$ & 0.729 \\
& $(0.158)$ & $(0.185)$ & $(0.138)$ & \\
Individual incentive to tertiary education & $-0.405^{a}$ & $0.322^{a}$ & -0.096 & 0.735 \\
& $(0.143)$ & $(0.147)$ & $(0.142)$ & \\
\hline \hline
\end{tabular}

Note : Standard deviations under parentheses $;{ }^{a},{ }^{b}$ and ${ }^{c} 1 \%, 5 \%$ and $10 \%$ significance level respectively. Standard deviations account for error correlations for each host.

\section{Alternative sources of institutional data}

The IP database covers a large array of subjects in a consistent way, but for a limited number of countries (52, mostly emerging countries) and only one year (2001). In order to address potential selection bias, we use alternative databases that offer institutional variables close to some of the IP variables used in the above estimations. The correspondence between IP variables and alternative sources is presented in Table 5, together with the correlation calculated on the same sample of countries, for the closest year available. Note that Fraser variables have been inverted when necessary to be consistent with IP variables for their interpretation. The highest correlations between the two sources are obtained for public sector efficiency, support to $R \& D$, and property rights security. The lowest are for bank competition and labor market regulations. Overall, most matches of institutional variables are validated by the correlations, although the case is less clear for the institutional distance variable.

TAB. 5 - Correspondence between IP and alternative sources on institutions

\begin{tabular}{|c|c|c|c|c|c|c|c|}
\hline \multicolumn{3}{|c|}{ New variable } & \multicolumn{2}{|r|}{ IP variable } & \multicolumn{3}{|c|}{ Correlations } \\
\hline var & label & source & var & label & orig. & dest. & dist. \\
\hline bur & Bureaucracy & FRA & b301 & Easiness to create a company & 0.284 & 0.259 & -0.011 \\
\hline capi & $\begin{array}{l}\text { Gap to max. stock market ca- } \\
\text { pitalization (\% GDP) }\end{array}$ & WDI & a700 & $\begin{array}{l}\text { Weak concentration of capi- } \\
\text { tal }\end{array}$ & 0.444 & 0.414 & 0.214 \\
\hline child & $\begin{array}{l}\% \text { children aged } 10-14 \text { not in } \\
\text { active pop. }\end{array}$ & WDI & a504 & $\begin{array}{l}\text { Parents' investment in edu- } \\
\text { cation }\end{array}$ & 0.481 & 0.529 & 0.308 \\
\hline compbank & Banking competition level & FRA & c701 & Competition - banks & 0.086 & 0.044 & -0.122 \\
\hline credit & Credit extension & FRA & c600 & Traditional credit systems & 0.314 & 0.232 & -0.102 \\
\hline credreg & Credit market regulation & FRA & c705 & Internal control of banks & 0.536 & 0.565 & 0.199 \\
\hline entry & Entry admin. conditions & FRA & b301 & Easiness to create a company & 0.361 & 0.327 & 0 \\
\hline firing & $\begin{array}{l}\text { Legal constraints on recrui- } \\
\text { ting and firing }\end{array}$ & FRA & d600 & $\begin{array}{l}\text { Existence and enforcement } \\
\text { of labor laws }\end{array}$ & 0.379 & 0.318 & 0.081 \\
\hline govest & Government efficiency & KAU & a305 & $\begin{array}{l}\text { Government efficiency - evo- } \\
\text { lution }\end{array}$ & 0.78 & 0.775 & 0.528 \\
\hline labbarg & $\begin{array}{l}\% \text { labour force with decen- } \\
\text { tralized wage negotiation }\end{array}$ & FRA & d701 & $\begin{array}{l}\text { Decentralization of wage } \\
\text { bargaining }\end{array}$ & 0.484 & 0.455 & 0.184 \\
\hline
\end{tabular}


CEPII, Working Paper No 2005-05.

\begin{tabular}{|c|c|c|c|c|c|c|c|}
\hline \multicolumn{8}{|c|}{ continued } \\
\hline \multicolumn{3}{|c|}{ New variable } & \multicolumn{2}{|r|}{ IP variable } & \multicolumn{3}{|c|}{ Correlations } \\
\hline var & label & source & var & label & orig. & dest. & dist. \\
\hline prop & Property rights security & FRA & $\mathrm{a} 601$ & $\begin{array}{l}\text { Security of formal property } \\
\text { rights }\end{array}$ & 0.674 & 0.684 & 0.362 \\
\hline rd & R\&D spending (\% GDP) & WDI & a501 & $\begin{array}{l}\text { Support to R\&D and innova- } \\
\text { tion }\end{array}$ & 0.727 & 0.746 & 0.45 \\
\hline
\end{tabular}

Source $:$ FRA $=$ Fraser Institute, WDI = World Bank World Development Indicators database, $\mathrm{KAU}=$ Kaufmann, Kraay and Zoidon-Lobatón database.

Equation 5 is now re-estimated using the alternative measures listed in Table 5, still in crosssection, for the latest year where data for FDI and the considered institutional variable are simultaneously available. These new results (unreported to save space) confirm the role of some variables in the attraction of FDI : Market capitalization, credit market regulations, free entry, public sector efficiency. It provides opposite results for R\&D support and for some labor market institutions. More importantly, these new results underscore the role of source country institutions which are always positive and generally significant. Results on institutional distance are not drastically improved. When significant, institutional distance coefficients are as often negative as they are positive. The new results underline concentration of capital and credit regulations as the two institutional variables that seem to matter for the source, the host and through the institutional distance altogether : Higher concentration of capital (or a more regulated credit market) raises both outward and inward FDI, especially if both countries display similar levels of concentration (or market regulation). Finally, comparing the results with those obtained with the IP database shows that public sector efficiency is a very robust determinant of both outward and inward FDI.

Last, we exploit the time dimension of the Fraser database (every 5 years since 1985), by re-estimating Equation 5 with panel data on Fraser Institute institutional variables only. Fixed effects on source countries and on host countries are introduced in each of those regressions, so that the coefficients on source and host country-specific variables should be interpreted as the impact of the evolution of those variables over time (there are also year dummy variables in the regression, to take into account the potential simultaneous global evolution of FDI and improvement in institutions). The results are displayed in Table 6. Strikingly, the coefficient on institutional distance generally becomes significant and negative, meaning that closer institutions between the source country and the host country tends to raise bilateral FDI. One possible interpretation of this discrepancy between cross-country and panel-data estimations is that FDI tends to rise more over time between countries with converging institutions (although in the short run institutional reforms can be detrimental to inward FDI). This again sounds like an encouraging result, meaning that efforts towards adopting the same quality of institutions as source countries could help developing countries to receive more FDI. 
ТАВ. 6 - Panel data estimations using Fraser Institute data for institutional variables

\begin{tabular}{||l|ccc|cc||}
\hline \hline \multirow{3}{*}{ Institution : } & \multicolumn{4}{|c||}{ Dependent Variable : ln $\left(0,3+\mathrm{FDI}_{i j}\right)$} \\
\cline { 2 - 6 } Bureaucracy & origin & destination & distance & $\mathrm{R}^{2}$ & $\mathrm{~N}$ \\
\hline & 0.004 & 0.003 & $-0.149^{a}$ & 0.826 & 1950 \\
Credit extension & $(0.063)$ & $(0.052)$ & $(0.036)$ & & \\
& $-0.171^{a}$ & -0.004 & $-0.166^{a}$ & 0.813 & 1868 \\
Credit market regulation & $(0.071)$ & $(0.06)$ & $(0.036)$ & & \\
& 0.009 & 0.045 & $-0.164^{a}$ & 0.802 & 2746 \\
Entry administrative conditions & $(0.039)$ & $(0.037)$ & $(0.029)$ & & \\
& $-0.134^{a}$ & $0.105^{a}$ & $-0.206^{a}$ & 0.808 & 2819 \\
Legal constraints on recruiting and firing & $(0.043)$ & $(0.041)$ & $(0.025)$ & & \\
Intellectual property rights & 0.126 & $0.402^{b}$ & 0.179 & 0.842 & 1159 \\
& $(0.2)$ & $(0.224)$ & $(0.122)$ & & \\
Judiciary system & $-0.147^{a}$ & $-0.192^{a}$ & 0.001 & 0.819 & 2482 \\
& $(0.052)$ & $(0.049)$ & $(0.025)$ & & \\
\% lab. force with decentralized wage nego. & 0.082 & 0.017 & $-0.104^{a}$ & 0.823 & 1981 \\
& $(0.086)$ & $(0.075)$ & $(0.027)$ & & \\
Property rights security & -0.082 & 0.033 & $-0.083^{a}$ & 0.824 & 1934 \\
& $(0.133)$ & $(0.143)$ & $(0.026)$ & & \\
& 0.058 & $0.223^{a}$ & -0.027 & 0.815 & 2716 \\
& $(0.047)$ & $(0.048)$ & $(0.023)$ & & \\
\hline \hline
\end{tabular}

Note : Results from estimations of equation 5 for each considered institutional variable. Each of the regressions have host and origin fixed effects together with year dummies. Standard deviations under parentheses $;{ }^{a},{ }^{b}$ and ${ }^{c} 1 \%, 5 \%$ and $10 \%$ significance level respectively. Standard deviations account for error correlations for each host. 


\section{Conclusion}

In this paper, we study in detail the impact of institutional "quality" on bilateral FDI. The detailed institutional database of the French Ministry of Finance has been used to highlight the main institutions that matter, and a number of robustness checks have been performed with other existing databases. In addition, the multicollinearity between most measures of institutional quality and the endogenous relationship between institutions and the level of development have been tackled.

We find that institutions matter independently of GDP per capita. Our results point out public efficiency in a broad sense as a major determinant of inward FDI. This includes tax systems, easiness to create a company, lack of corruption, transparency, contract law, security of property rights, efficiency of justice and prudential standards. The extent of competition is also shown to matter, although capital concentration in both the source and the destination country has a positive impact on FDI.

While "good" institutions almost always increase the amount of FDI received, no general result applies to outward FDI. Finally, panel data regressions show that institutional distance tends to reduce bilateral FDI, although the results are much more mixed in the cross section dimension.

These results are encouraging in the sense that efforts towards raising the quality of institutions and making them converge towards those of source countries may help developing countries to receive more FDI, hence help them to catch up, independently of the indirect impact of higher GDP per capita. The orders of magnitude found in the paper are large, meaning that moving from a low level to a high level of institutional quality could have as much impact as suddenly becoming a neighbor of a large source country.

\section{References}

Acemoglu, D., Johnson, S., And J.Robinson (2001), "The Colonial Origins of Comparative Development : An Empirical Investigation", American Economic Review.

Acemoglu, D., Johnson, S., And J.Robinson (2002), "Reversal of Fortune : Geography and Institutions in the Making of the Modern World Income Distribution", Quarterly Journal of Economics.

Aizenman, J., And M.M. SPiegel (2002), "Institutional Efficiency, Monitoring Costs, and the Investment Share of FDI", NBER working paper 9324.

Alesina A., Baqir, R., AND W. EATerly, (1999) "Public Goods and Ethnic Divisions", Quarterly Journal of Economics, CXIV(4) :1243-1284.

Berthelier P., Desdoigts, A., And J. Ould Aoudia (2003), "Presentation and Analysis of an Original Database of the Institutional Characteristics of Developing, 
in Transition and Developed Countries", mimeo University of Bourgogne.

Brun J-F., Carrere, C., De Melo, J., And P. Guillaumont (2002), "Has Distance Died ? Evidence from a Panel Gravity Model”, CEPR Discussion Paper \# 3500.

Disdier, A-C., And K. Head (2004), "The Puzzling Persistence of the Distance Effect on Bilateral Trade", Mimeo, University of British Columbia.

DrabeK, Z., AND W. PAYNe (2002), "The Impact of Transparency on Foreign Direct Investment", Journal of Economic Integration, 17 (4), pp. 777-810.

EATON, J. AND A.TAMURA (1994), "Bilateralism and Regionalism in Japonese and U.S. Trade and Direct Foreign Investement Patterns", Journal of the Japanese and International Economies 8 :478-510.

FeEnstra, R. (2003), Advanced International Trade : Theory and Evidence, Princeton : Princeton University Press.

IMF (2003), World Economic Outlook, Chapter III.

Globerman, S. AND D. Shapiro (2002), "Global Foreign Direct Investment Flows : The Role of Governance Infrastructure”, World Development 30(11):1899-1919.

Globerman, S. AND D. Shapiro (2002), "Governance Infrastructure and U.S. Foreign Direct Investment", Journal of International Business Studies.

HABib, M., AND L. ZURAWICKI (2002), "Corruption and Foreign Direct Investment", Journal of International Business Studies 33 (2).

Hall, R., AND C.Jones (1999), "Why do some countries Produce So More Output per Worker Than Others ?", Quarterly Journal of Economics 114 :83-116.

Heckman, J. (1979), "Sample Selection Bias as a Specification Error", Econometrica, 47 153-161.

Kaufmann, D., And A.KraAy (2002), Growth Without Governance, The World Bank.

KaUfmann, D., KraAy, A., AND P.ZoIdo-LobATÓn (1999), Aggregating Governance Indicators, Policy Research Paper 2195, The World Bank.

Kinoshita, Y., And N. Campos (2003), "Why Does FDI Go Where it Goes? New Evidence from the Transition Economies", Williamson Institute Working paper, 573.

LaPorta, R., Lopez-DE-Silanes, F., Shleifer, A., AND R.Vishny (1998a), "Legal Determinant of External Finance", Journal of Political Economy 106 1113-1155.

LaPorta, R., Lopez-De-Silanes, F., Shleifer, A., And R.Vishny (1998b), "The Quality of Government", NBER Working Paper 7403.

LAPorta, R., LoPEZ-DE-Silanes, F., Shleifer, A., AND R.Vishny (1999), "Investor Protection and Corporate Valuation", NBER, mimeo.

LaPorta, R., Lopez-De-Silanes, F., Shleifer, A., AND R.Vishny (2001), "Investor Protection and Corporate Governance", Harvard University, mimeo. 
Larraín, F.B., And J. TAVAres (2004), "Does Foreign Direct Investment Decrease Corruption?", Cuadernos de Economia, 41, pp. 217-230.

LEVCHENKo, A. (2004), "Institutional Quality and International Trade", HIMF Working Paper, 04/231.

Levine, R. (1998), "The Legal Environment, Banks and Long-Run Economic Growth", Journal of Money, Credit and Banking 30 596-613.

LuCAs R. (1990), “Why Doesn't capital Flow from Rich to Poor Countries ?", American Economic Review 80 (2) 92-96.

MaUro, P. (1995), “Corruption and Growth", Quaterly Journal of Economics, 110(août) 681-712.

MÉOn, P.-G., AND K. SEKKAT (2004), "Does the Quality of Institutions Limit the MENA's Integration in the World Economy ?", The World Economy, 27 (9) pp. 14751498.

NoRTH, D. (1990), "Institutions, Institutional Change and Economic Performance", Cambridge University Press

RODRIK, D. (2004), “Getting Institutions Right”, mimeo, Harvard University, April.

Rodrik, D., Subramanian, A., And F.Trebbi (2002), "Institutions Rule : The Primacy of Institutions over Integration and Geography in Economic Development", IMF Working Paper.

STEIN, E., AND C. DAUdE (2001), "Institutions, Integration and the Location of Foreign Direct Investment”, Inter-American Development Bank.

Tinbergen, J. (1962),"Shaping the World Economy - Suggestions for an International Economic Policy", The Twentieth Century Fund.

WEI, S.-J. (1997), “How Taxing is Corruption on International Investors ?”, NBER Working Paper 6030.

WEI, S.-J., 2000, "How taxing is corruption on internal investors ?", The Review of Economics and Statistics, 82(1) : 1-11.

WheEler, D., AND A. MOdY, 1992, "International investment location decisions. The case of U.S. firms", Journal of International Economics, 33 : 57-76.

United Nations, World Investment Report, 2004. 